\section{Studying Japan: Handbook of Research Designs, Fieldwork and Methods}

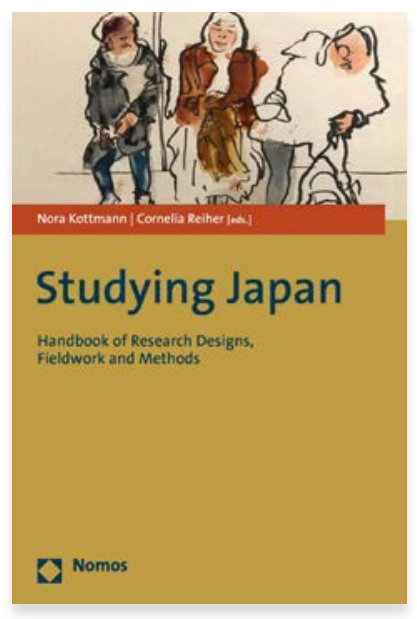

\section{NORA KOTTMANN AND CORNELIA REIHER (EDS).}

Nomos Verlagsgesellschaft

(Baden-Baden, Germany), 2020.

501 pages.

ISBN13: 9783848750856.

ISBN10: 9783845292878.

https://doi.org/10.5771/9783845292878

\section{Reviewed by}

\section{Gwyn McClelland}

University of New England

https://orcid.org/0000-0002-6914-2387

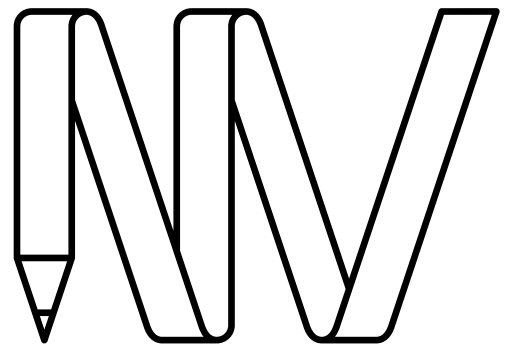

NEW

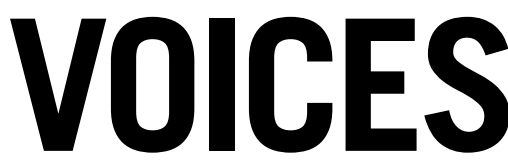

IN JAPANESE STUDIES

\title{
KEYWORDS
}

fieldwork; handbook; methods; qualitative research

Studying Japan: Handbook of Research Designs, Fieldwork and Methods $\checkmark$ claims to be, and is in my view, "the first comprehensive guide on qualitative methods, research designs and fieldwork in social science research on Japan" (n.p.). As a 'how-to' book for established and beginning scholars, it describes the ins and outs of social science research on Japan from multiple perspectives, providing definitions, examples and an up-to-date bibliography. As a methodology and research volume, this book presents an impressive breadth of material and methodological guidance, as well as expert opinion and experience.

Some more limited books on social science research methodologies in the Japanese context should be considered forerunners to this volume, for example Bestor et al. (2003), which included twenty-one contributors who were located in Northern America or Europe. But this new collection, which has originated of German leadership, is broader and much more inclusive in scope. It showcases the work of over seventy Japan scholars located at universities around the world, including the United States, Hong Kong, Europe, Australia and Japan. The backgrounds of the academics are varied: the volume is

\section{JAPANFOUNDATION 8 BRINGING JAPAN TO YOU \\ To link to this article: https://doi.org/10.21159/nvjs.13.r-03}

\section{ISSN 2205-3166}

New Voices in Japanese Studies is an interdisciplinary, peer-reviewed journal showcasing the work of emerging scholars with ties to Australia or New Zealand and research interests in Japan.

All articles can be downloaded free at $\underline{\text { newvoices.org.au }}$

(C) The Japan Foundation, Sydney and Gwyn McClelland, 2021.

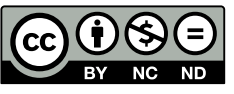

This work is licensed under a Creative Commons Attribution-NonCommercialNoDerivatives 4.0 International License. 
notable for its cross-disciplinary calibre, broad gender balance and the breadth of perspectives represented. The content will also resonate with the needs and priorities of today's scholars. To take one simple example, Brigitte Steger's essay (474-77) shares advice on how to publish research that engages with the twenty-first century media, thereby increasing reach and impact. She considers how researchers might nowadays be able to get their work into the news, referring to how her own article published by BBC Worldwide received 1.4 million individual browser hits in its English version. Steger shows how as researchers increase their popular reach, they demonstrate their expertise, likely leading to new opportunities.

The editors, Nora Kottmann (senior research fellow at the German Institute for Japanese Studies, Tokyo) and Cornelia Reiher (vice director of the Freie Universitat Graduate School of East Asian Studies in Berlin), have done an admirable job of allowing the voices of a diverse group of Japan scholars to be heard in an instructive format which allows for incisiveness and clarity. Studying Japan broadly guides the reader in how to approach qualitative research in Japan from start to finish. The book's chapter titles map out the major steps in planning and executing a research project, starting with "How to Begin Research" (Chapter 1), continuing on to "An Introduction to Qualitative Social Science Methods" (Chapter 5), "How to Do Fieldwork" (Chapter 6), "How to Access Written and Visual Sources" (Chapter 9), "How to Understand Discourse" (Chapter 14), and finally "How to Present Findings" (Chapter 17). Each chapter introduces a broad discussion of a topic, followed by three shorter essays which often include real-world examples that encapsulate some of the relevant issues within the discussion. The book also contains a treasure trove of links to helpful resources, as the chapters are rounded off with suggestions for further reading in addition to the list of references.

Given that there are seventeen chapters and fifty-one essays over the 500 pages in this volume, I will struggle in this review to cover the breadth of material in detail. However, I will briefly discuss a few examples of the impressive colour and diversity of approaches which are explored within each theme, and the engaging writing throughout. In Chapter 11, "How to Analyse Data" by David Chiavacci of Zurich University, the discussion begins:

"Data analysis is like baking a cake [...]. The raw data or materials you have collected are just as important to your argument as the ingredients-sugar, eggs, flour-are for baking a cake [...]. Not many people will be interested in your raw data-or ingredients - as such, but an innovative argument or a good cake might bring you fame."

(300)

This particular introduction reminded this reviewer of the Foreword to StudyingJapan, in which Franz Waldenberger, Director of the German Institute for Japanese Studies, writes that while the book does not intend to be a bible of Japanese Studies, it might well be a book of recipes showing how to make your research "relevant and convincing" (13). On the other hand, Chiavacci goes on to remind us in his chapter that this material metaphor can only take us so far in social science research. Our positionality as researchers and the ever- 
present potential for difficulties and conflicts arising around power and bias do not resemble "making a cake" (309). A 'how-to' manual can take research so far, but the rest is up to the researcher.

I would be remiss not to mention some of the other notable inclusions in the volume, such as multiple reflections on ethnography and analysis of subculture, as well as considerations about emotion and affect, and how to use mixed methods in research. Chapter 9, "How to Access Written and Visual Sources: Archives, Libraries and Databases" offers a further exemplar. Here the researcher will find practicalities about accessing archives in Japan-including "tricky sources" (248) such as business documents or war memorials-and how one might use quantitative data for qualitative research. The emphasis upon know-how will certainly add to researchers' tool-kits, as will the recent online datasets and archives referenced here.

As an oral historian myself, one of the first sections I wished to look into was Chapter 7, "How to Interview People: Qualitative Interviews", written by Kottmann and Reiher. They broadly introduce the concept of qualitative interviews, including how to find interviewees, preparation for interviews, language and the process of communicating with informants, and how to be a skilled listener. They examine the question of language (it is vital) for the researcher in Japan, and include a commentary on the socio-cultural importance of expressing appreciation after interviews, amid discussion on interviewing in the Japanese context. The main chapter is followed by essays which add on-the-ground practicalities to the discussion, from three scholars who have used interviews in their own research: Christoph Brumann, Tomiko Yamaguchi (a Japanese perspective) and Allison Alexy. Each author approaches the topic from a distinctive point of view, and each of the three essays incorporates a specific subtitle which clearly alerts the reader to its focus, such as, for example, Allison Alexy's "Talking through Difficult Topics". Of the three, Brumann is more reflective and pragmatic, while Alexy expands on how the interviewer is involved in the research through their own positionality, noting that being a non-Japanese citizen comes with some advantages when carrying out interviews in Japan. Yamaguchi agrees with Alexy on this point, observing that interviewees may be more ready to open up to researchers from outside of Japan.

As a handbook, this is a book to dip into which goes well beyond Japanese Studies, like the theme of this special issue, in breadth and discussion. The reader may easily follow tangential topics throughout the text, as crossreferences are frequently provided in brackets, leading from one part of the volume to another. One area not covered comprehensively and which might make a useful addition in the future is digital humanities, considering its importance for the kinds of qualitative research described in this volume. As well, one might note that this volume was written in an era which pre-dates the COVID-19 pandemic, so researchers who are considering fieldwork in Japan will need to additionally take stock of the last two years in particular.

The impacts of COVID-19 have changed expectations around travel and crossing borders, and will undoubtedly have a major impact on the research 
methods discussed here as well as upon the expectations and needs of those whom the researcher will encounter.

Nonetheless, there is no doubt that Studying Japan is a first of its kind, and a book I wish had been available when I was doing my own $\mathrm{PhD}$. I will certainly recommend the volume to my own students, and have already found myself incorporating references to it into workshops on research methodology. NonJapan specialists and other area studies researchers will certainly be interested in the advice and discussions about social science research. Here we have not only vignettes of research experiences and incisive advice and discussion about preparation, the process of research and the writing, but also an extraordinary source book, with references to the latest and most useful literature. This is in effect an encyclopaedia of Japanese Studies research methodologies and as such is essential reading for specialists, students of Japan and others with an interest in navigating the field.

\section{REFERENCES}

Bestor, T., Steinhoff, P. and Bestor, V., eds. 2003. Doing Fieldwork in Japan. Honolulu: University of Hawaii Press. 